\title{
Hydrogen Peroxide Release and Acid-Base Status in Exhaled Breath Condensate at Rest and after Maximal Exercise in Young, HeAlthy Subjects
}

\author{
E. Marek ${ }^{1,3}$, P. Platen ${ }^{1}$, J. Volke 1 , K. Mückenhoff 2 , W. Marek ${ }^{3}$ \\ ${ }^{1}$ Institute of Sportsmedicine and Sportnutrition and ${ }^{2}$ Institute of Physiology, Ruhr-Universität Bochum, Bochum, Germany; \\ ${ }^{3}$ Institute of Occupational Physiology, Augusta Kranken Anstalt, Bochum, Germany
}

\begin{abstract}
Objective: Exhaled breath condensate (EBC) contains among a large number of mediators hydrogen peroxide $\left(\mathrm{H}_{2} \mathrm{O}_{2}\right)$ as a marker of airway inflammation and oxidative stress. Similarly EBC pH also changes in respiratory diseases. It was the aim of our investigation to prove if hydrogen peroxide release and changes in $\mathrm{pH}$ of EBC changes with exercise.

Methods: EBC was collected from 100 litres exhaled air along with samples of arterialized blood of 16 healthy subjects ( 9 males, 7 females, age $23 \pm 1$ years). EBC hydrogen peroxide was analyzed with EcoCheck amperometer (FILT, Berlin). The rate of $\mathrm{H}_{2} \mathrm{O}_{2}$ release was calculated from the concentration and collection time. $\mathrm{pH}$ and $\mathrm{PCO}_{2}$ in blood and in $\mathrm{EBC}$ were measured with the Radiometer blood gas analyzer, $\mathrm{EBC}$ was equilibrated with a gas mixture $\left(5 \% \mathrm{CO}_{2}\right.$ in $\left.\mathrm{O}_{2}\right)$. The bicarbonate concentration was calculated according to the law of mass action for $\mathrm{CO}_{2}$ and $\mathrm{HCO}_{3}{ }^{-}(\mathrm{pK}=6.1)$. Results: $\mathrm{H}_{2} \mathrm{O}_{2}$ concentration in $\mathrm{EBC}$ was $190 \pm 109$ $\mathrm{nmol} / \mathrm{l}$, and $\mathrm{H}_{2} \mathrm{O}_{2}$ release at rest was $31.0 \pm 18.3$ $\mathrm{pmol} / \mathrm{min}$. At maximal exercise, the $\mathrm{H}_{2} \mathrm{O}_{2}$ concentration in EBC increased to $250 \pm 120 \mathrm{nmol} / 1$, and $\mathrm{H}_{2} \mathrm{O}_{2}$ release significantly increased at maximal exercise to $84.4 \pm 39.9 \mathrm{pmol} / \mathrm{min}(\mathrm{P}<0.01)$. At rest $\mathrm{pH}$ of the $\mathrm{CO}_{2}$ equilibrated $\mathrm{EBC}$ was at $6.08 \pm 0.23$ and the $\left[\mathrm{HCO}_{3}{ }^{-}\right]$was $1.03 \pm 0.40 \mathrm{mmol} / 1$. At maximum exercise, $\mathrm{pH} 6.18 \pm 0.17$ and $\left[\mathrm{HCO}_{3}^{-}\right] 1.23 \pm 0.30 \mathrm{mmol} / 1$ remained almost unaltered.

Conclusions: The rate of $\mathrm{H}_{2} \mathrm{O}_{2}$ release in $\mathrm{EBC}$ increased during exhausting exercise (external load: 300 Watt) by a factor of 2 , whereas the $\mathrm{pH}$ and the bicarbonate concentration of the $\mathrm{EBC}$, equilibrated with $5 \% \mathrm{CO}_{2}$ at $37^{\circ} \mathrm{C}$ were not significantly altered. It has to be proven by further experiments whether there is a linear relationship between the rates of $\mathrm{H}_{2} \mathrm{O}_{2}$ release in $\mathrm{EBC}$ in graded submaximal exercise.

Key words: reference values, exhaled breath condensate, oxidative stress, hydrogen peroxide, respiration, spirometry
\end{abstract}

\section{INTRODUCTION}

Exhaled breath condensate (EBC) contains a large number of mediators, which are influenced by airway infections and other lung diseases and modulated by therapeutic intervention. Among others there is hydrogen peroxide $\left(\mathrm{H}_{2} \mathrm{O}_{2}\right)$, which can be measured by currently developed micro enzyme detectors of high sensitivity.

$\mathrm{H}_{2} \mathrm{O}_{2}$ is released by neutrophils and eosinophils and by macrophages and epithelial airway cells; it provides one line of defence should infection occur and is therefore the most important marker of airway infection. It is synthesised by superoxide dismutase induced reaction of $\mathrm{O}^{-}$radicals and $\mathrm{H}^{+}$ions. A peroxidase is secreted by airway epithelial cells, which converts hydrogen peroxide into hypothiocyanous acid, a toxic compound that kills pathogens.

Similarly exhaled breath condensate (EBC) $\mathrm{pH}$ also changes in respiratory diseases. Like in other body fluids $\mathrm{pH}$ homoestasis is maintained by the interacting acid-base- and buffer systems, mainly influenced by the $\mathrm{CO}_{2}$-bicarbonate reaction of the extracellular fluid. Therefore the $\mathrm{pH}$ of $\mathrm{EBC}$ is found to be unstable outside the airway tract, due to the volatility of $\mathrm{CO}_{2}$ molecules leaving the fluid. This results in a decreased $\mathrm{CO}_{2}$ and bicarbonate with an increasing $\mathrm{pH}$ of the EBC.

Argon deaeration was suggested as a method to keep the $\mathrm{pH}$ constant. This increases the reproducibility of the measurements. Deaerated samples turned out to be stable, not influenced by hypo-or hyperventilation and independent from environmental temperature time of storage. In our study, we preferred the method of keeping the $\mathrm{CO}_{2}$ partial pressure of the EBC constant by equilibration with a $5 \% \mathrm{CO}_{2}$ gas mixture thus simulating a mean $\mathrm{CO}_{2}$-fraction within the lung. Furthermore the experiments were designed to determine bicarbonate, the main buffer within the $\mathrm{pH}$ range of $\mathrm{EBC}$ in vivo.

The aim of the investigation was to prove, if maximal exercise results in an increased rate of hydrogen peroxide release and an altered acid-base status of EBC. In a group of young and healthy subjects we measured $\mathrm{H}_{2} \mathrm{O}_{2}$ and $\mathrm{pH}$ of the equilibrated $\mathrm{EBC}$ (with a $5 \% \mathrm{CO}_{2}$ gas mixture) before and after exhausting exercise. 


\section{Material AND Methods}

\section{ANTHRopometrical Data of SubJects INVESTIGATED}

The investigation was carried out on 16 healthy sporting subjects ( 9 males, 7 females), age $23 \pm 1$ years (range 22-26 years), $175 \pm 8.4 \mathrm{~cm}$ height, and normal BMI $22.2 \pm 1.7 \mathrm{~kg} / \mathrm{m}^{2}$ (range $19.7-24.8 \mathrm{~kg} / \mathrm{m}^{2}$ ). The subjects were free from acute airway infections and had, according to the ECCS references [1], highly normal values for the forced vital capacity (males $113 \pm$ $11.4 \%$ pred and females $108 \pm 10.3 \%$ pred). Mean values for FEV1 were highly normal, $105.7 \pm 8.8 \%$ pred in females and $119.1 \pm 10,5 \%$ pred in males. Tiffeneau Index another marker for airway obstruction was also highly normal in all subjects (males $107 \pm 4.5 \%$ pred and $102 \pm 5.9 \%$ pred).

\section{PRotocol}

The subjects performed bicycle exercise (Ergoline E900), preferentially in the morning hours in a air conditioned room, following a protocol used in performance evaluation of athletes, starting with $5 \mathrm{~min}$ utes at 50 Watt and increasing external load by 50 Watt every 3 min. Respiratory parameters, using a medium sized face mask and heart rate (Polar belt) were continuously recorded by a ZAN 600USB CPA spiroergometer (ZAN Oberthulba, Germany). Before each test appropriate calibrations of the air-flow sensor and $\mathrm{O}_{2^{-}}$and $\mathrm{CO}_{2}$-sensors were performed, with calibration gases from cylinders $\left(5 \% \mathrm{CO}_{2}, 16 \% \mathrm{O}_{2}, 79 \% \mathrm{~N}_{2}\right)$ and ambient air. During rest and immediately after the exercise 100 litres exhaled air and samples of aterialized blood of the ear lobe were collected. 1001 exhaled air at $37^{\circ} \mathrm{C}$ saturated with water vapour should contain $4.3 \mathrm{ml}$ water [2].

EBC was obtained by cooling 1001 expired to $-20^{\circ} \mathrm{C}$ (ECoScreen I, FILT, Berlin). At rest $100 \mathrm{l}$ exhaled air were collected in $8.4 \pm 2.0 \mathrm{~min}$ and $1.68 \pm$ $0.39 \mathrm{ml}$ EBC obtained. After exhausting exercise at $220 \pm 23,5$ Watt 1001 of exhaled air were collected in $3.9 \pm 1.8 \mathrm{~min}$ and $1.20 \pm 0.44 \mathrm{ml} \mathrm{EBC}$ collected. The volumes represent $39.1 \%$ and $27.9 \%$ of the theoretical water vapour contend of 1001 exhaled air. From the EBC sample, three aliquots were taken for lactate, $\mathrm{H}_{2} \mathrm{O}_{2}$, and $\mathrm{pH}$ and acid base measurements. The samples were stored on ice, deep frozen to $-12^{\circ} \mathrm{C}$.

$\mathrm{H}_{2} \mathrm{O}_{2}$ analysis was performed amperometrically after conversion of $\mathrm{H}_{2} \mathrm{O}_{2}$ by peroxidase $\left(\mathrm{H}_{2} \mathrm{O}_{2} \rightarrow 2 \mathrm{H}^{+}\right.$ $\left.+\mathrm{O}_{2}+2 \mathrm{e}^{-}\right)$using miniaturized enzyme detectors (ECoCheck, FILT, Berlin). Measurements can be performed in an effective range between 30-3000 nmol/1. Calibrations were performed daily. The method was described in detail in previous papers [3, 4]. Acid-base parameters were measured in crude EBC samples. $\mathrm{H}_{2} \mathrm{O}_{2}$ was measured in $0.3 \mathrm{ml}$ EBC diluted in $0.3 \mathrm{ml}$ buffer solution. The rate of release from the lung ( $\mathrm{mol} / \mathrm{min})$ is calculated from the concentration of hydrogen peroxide and the collection time of EBC. $\mathrm{pH}$ and $\mathrm{PCO}_{2}$ measurements of EBC (equilibrated with a gas mixture of $5 \% \mathrm{CO}_{2}$ in oxygen at $37^{\circ} \mathrm{C}$ ) and of blood taken from the ear lobe are performed with a blood gas analyzer (Radiometer ABL520, Copenhagen) [5]. $\mathrm{HCO}_{3}{ }^{-}$is calculated according to the mass action law of the $\mathrm{CO}_{2}$-bicarbonate reaction $(\mathrm{pK}=6.1$; solubility of $\mathrm{CO}_{2}=0.03 \mathrm{mmol} / 1$ Torr). For $\mathrm{CO}_{2}$ equilibration a small PVC capillary was made for bubbling the carbogen through the EBC sample, filled into a $2 \mathrm{ml} \mathrm{Ep-}$ pendorf vial.

\section{STATISTICAL ANALYSIS}

Data were compiled in tables (Microsoft, Excel 2003). The final statistical analysis was performed using the SPSS 11.5 statistic program. After testing the data for homogeneity and normal distribution, means and standard deviations were calculated and presented in tables and Box-plots. Using Fisher's t-test for paired data, respiratory and cardiovascular data were tested for significant alterations $(\mathrm{P}<0.05)$.

\section{RESULTS}

\section{RESPIRATORY AND CARDiAC RESPONSES}

At maximum exercise ventilation increased nearly 10 fold to $123 \pm 21.3$ and $97.7 \pm 10.7 \mathrm{l} / \mathrm{min}$ in males and females, respectively. At maximum load, females reached a mean heart rate of $186 \pm 9.5$ beats $/ \mathrm{min}$ at $200 \pm 23.6$ Watt and males $180 \pm 6.3$ beats $/ \mathrm{min}$ at 241 \pm 24.9 Watt. Oxygen consumption increased to $44.9 \pm$ 3.3 and $49.6 \pm 6.6 \mathrm{ml} / \mathrm{min} / \mathrm{kg}$ in females and males, respectively. In all subjects, respiratory exchange rate (RER) exceeded the value of 1.00 , and reached $1.15 \pm$ 0.05 at break-off point in females and $1.14 \pm 0.07$ in males.

\section{EXHALED BREATH CONDENSATE}

Under resting conditions, 1001 of exhaled air was collected within $8.4 \pm 2.0 \mathrm{~min}$, which delivered $1.68 \pm$ $0.39 \mathrm{ml} \mathrm{EBC}$. This volume of fluid is $39.1 \%$ of the theoretical water content of 1001 of air saturated with water at $37^{\circ} \mathrm{C}$. After maximal exercise, the collection time was $3.9 \pm 1.8 \mathrm{~min}(\mathrm{P}<0.05), \mathrm{EBC}$ volume was $1.20 \pm 0.44 \mathrm{ml}$, which is $27.9 \%$ of the theoretical water content.

\section{Hydroxygen Peroxide Release in EBC}

$\mathrm{H}_{2} \mathrm{O}_{2}$ concentration in EBC was $190 \pm 109 \mathrm{nmol} / \mathrm{l}$. At rest $\mathrm{H}_{2} \mathrm{O}_{2}$ release in the collected $\mathrm{EBC}$ was $31.0 \pm$ $18.3 \mathrm{pmol} / \mathrm{min}$ (Figs. 1 and 2). At maximal exercise (external load $220 \pm 20$ Watt), the $\mathrm{H}_{2} \mathrm{O}_{2}$ concentration in $\mathrm{EBC}$ increased to $250 \pm 120 \mathrm{nmol} / 1$, and $\mathrm{H}_{2} \mathrm{O}_{2}$ release significantly increased at maximal exercise to $84.4 \pm 39.9 \mathrm{pmol} / \mathrm{min}(\mathrm{P}<0.01)$ (Figs. 1 and 2$)$. Taking the theoretical water volumes of EBC into account the following maximal rates of release of hydrogen peroxide are calculated: $79.5 \pm 46.8 \mathrm{pmol} / \mathrm{min}$ at rest, $301 \pm 143 \mathrm{pmol} / \mathrm{min}(\mathrm{P}<0.01)$ at maximal exercise.

\section{ACID-BASE PARAmeters of EBC}

In Fig. 3 and Fig. 4 the $\mathrm{pH}$ and $\mathrm{HCO}_{3}{ }^{-}$, respectively, of the $\mathrm{EBC}$, which has been equilibrated with a humidified 


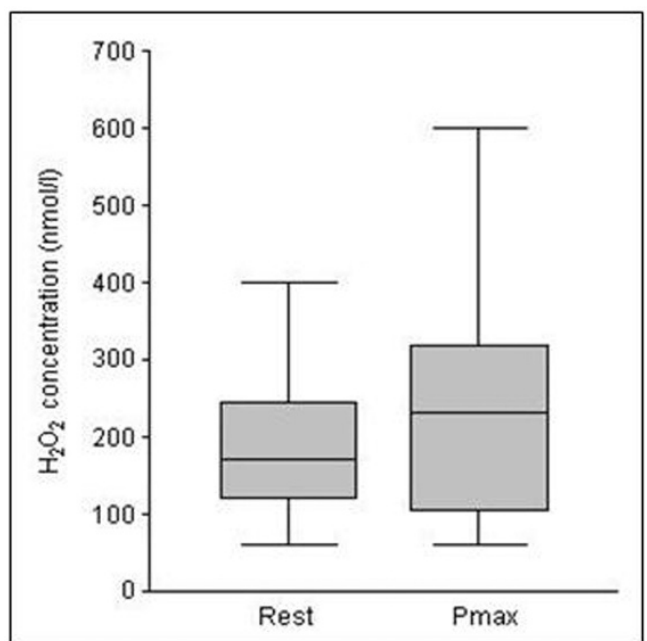

Fig. 1. $\mathrm{H}_{2} \mathrm{O}_{2}$ concentration in exhaled breath condensate (EBC) (nmol/1 EBC) at rest and after maximal load (Pmax).

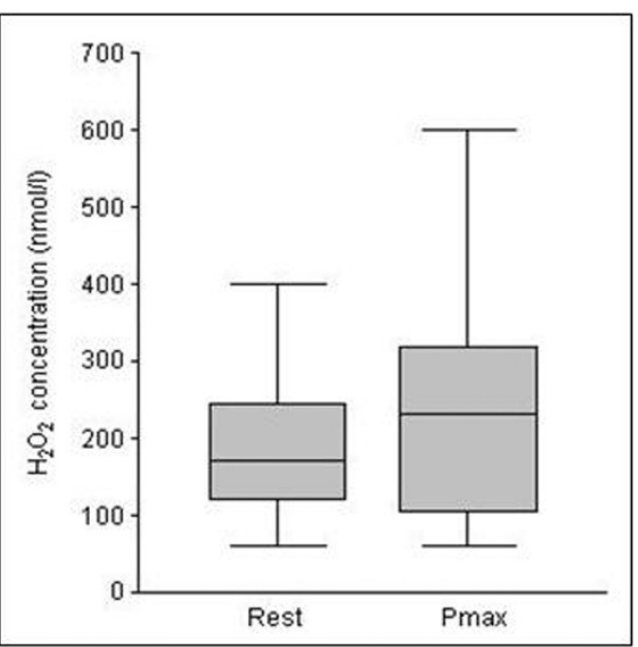

Fig. 2. $\mathrm{H}_{2} \mathrm{O}_{2}$ release $(\mathrm{pmol} / \mathrm{min})$ in exhaled breath condensate (EBC) at rest and after maximal load (Pmax).

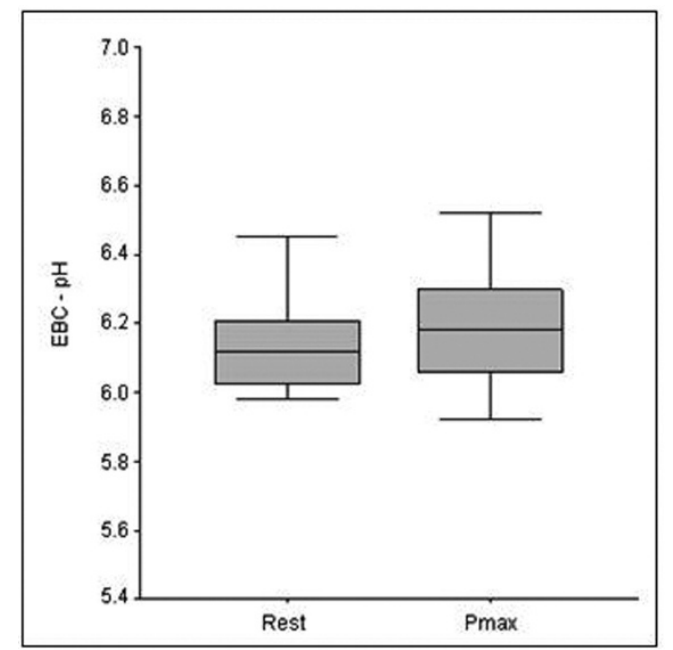

Fig. 3. $\mathrm{pH}$ of $5 \% \mathrm{CO}_{2}$-equilibrated exhaled breath condensate (EBC) at rest and after maximal load (Pmax).

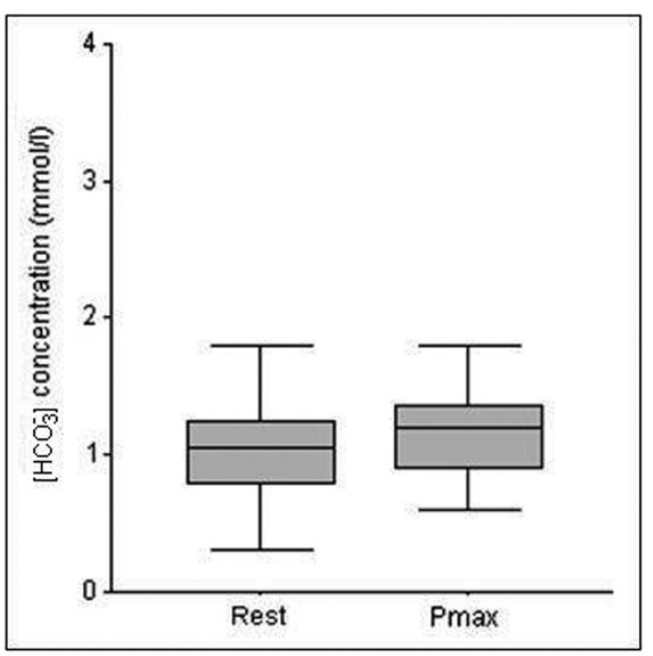

Fig. 4. Bicarbonate concentration (mmol/l EBC) in 5\% $\mathrm{CO}_{2}$-equilibrated exhaled breath condensate $(\mathrm{EBC})$ at rest and after maximal load (Pmax).

Table 1. Mean values of respiratory and cardio-vascular parameters at rest and after exhausting exercise.

\begin{tabular}{|c|c|c|c|c|c|c|c|c|c|c|}
\hline & & $\begin{array}{l}\text { VE } \\
(1 / \min )\end{array}$ & $\begin{array}{l}\mathbf{V} \mathbf{O}_{2} \\
(1 / \mathrm{min})\end{array}$ & $\begin{array}{l}\mathbf{V C O}_{2} \\
(1 / \mathrm{min})\end{array}$ & RER & $\begin{array}{l}\mathbf{V E} / \mathbf{V O} \mathbf{O}_{2} \\
(\mathrm{l} / \mathrm{min}) / \mathrm{lO}_{2}\end{array}$ & $\begin{array}{l}\mathbf{V} \mathbf{O}_{2} / \mathbf{k g} \\
(\mathrm{ml} / \mathrm{min} / \mathrm{kg})\end{array}$ & $\begin{array}{l}\text { HR } \\
(1 / \min )\end{array}$ & $\begin{array}{l}\text { O } 2 \text { Puls } \\
\left(\mathrm{ml} \mathrm{O}_{2} / \mathrm{Hs}\right)\end{array}$ & $\begin{array}{l}\text { External Load } \\
\text { (Watt) }\end{array}$ \\
\hline \multirow{2}{*}{ femal } & Rest & $\begin{array}{l}8.71 \\
\pm 1.76\end{array}$ & $\begin{array}{l}0.306 \\
\pm 0.071\end{array}$ & $\begin{array}{l}0.240 \\
\pm 0.068\end{array}$ & $\begin{array}{l}0.80 \\
\pm 0.16\end{array}$ & $\begin{array}{l}29.73 \\
\pm 8.80\end{array}$ & $\begin{array}{l}5.2 \\
\pm 1.5\end{array}$ & $\begin{array}{l}81.6 \\
\pm 7.6\end{array}$ & $\begin{array}{l}3.80 \\
\pm 1.01\end{array}$ & \\
\hline & $\mathrm{P}_{\text {Max }}$ & $\begin{array}{l}97.74 \\
\pm 10.69\end{array}$ & $\begin{array}{l}2.710 \\
\pm 0.211\end{array}$ & $\begin{array}{l}3.129 \\
\pm 0.295\end{array}$ & $\begin{array}{l}1.15 \\
\pm 0.05\end{array}$ & $\begin{array}{l}36.11 \\
\pm 3.42\end{array}$ & $\begin{array}{l}44.9 \\
\pm 3.3\end{array}$ & $\begin{array}{l}186.3 \\
\pm 9.5\end{array}$ & $\begin{array}{l}14.59 \\
\pm 1.45\end{array}$ & $\begin{array}{l}200.2 \\
\pm 23.6\end{array}$ \\
\hline \multirow{2}{*}{ male } & Rest & $\begin{array}{l}13.64 \\
\pm 2.63\end{array}$ & $\begin{array}{l}0.461 \\
\pm 0.137\end{array}$ & $\begin{array}{l}0.381 \\
\pm 0.108\end{array}$ & $\begin{array}{l}0.83 \\
\pm 0.11\end{array}$ & $\begin{array}{l}32.59 \\
\pm 13.63\end{array}$ & $\begin{array}{l}6.10 \\
\pm 0.75\end{array}$ & $\begin{array}{l}75.7 \\
\pm 7.6\end{array}$ & $\begin{array}{l}6.15 \\
\pm 1.90\end{array}$ & \\
\hline & $\mathrm{P}_{\text {Max }}$ & $\begin{array}{l}122.66 \\
\pm 21.27\end{array}$ & $\begin{array}{l}3.756 \\
\pm 0.467\end{array}$ & $\begin{array}{l}4.300 \\
\pm 0.506\end{array}$ & $\begin{array}{l}1.14 \\
\pm 0.07\end{array}$ & $\begin{array}{l}32.91 \\
\pm 5.68\end{array}$ & $\begin{array}{l}49.6 \\
\pm 6.6\end{array}$ & $\begin{array}{l}179.6 \\
\pm 6.3\end{array}$ & $\begin{array}{l}20.95 \\
\pm 2.77\end{array}$ & $\begin{array}{l}240.7 \\
\pm 24.9\end{array}$ \\
\hline
\end{tabular}

gas mixture of $5 \% \mathrm{CO}_{2}$ in oxygen are shown. At rest, the $\mathrm{pH}$ was $6.08 \pm 0.23$, the $\mathrm{PCO}_{2}$ was $32.8 \pm 3.5$ $\mathrm{mmHg}$, and the $\mathrm{HCO}_{3}{ }^{-}$was calculated at $1.03 \pm 0.40$ mmol/l. After maximal exercise, we found $\mathrm{pH} 6.18 \pm$ $0.17, \mathrm{PCO}_{2} 35.1 \pm 1.8 \mathrm{mmHg}$, and $\left[\mathrm{HCO}_{3}^{-}\right] 1.13 \pm$ $0.40 \mathrm{mmol} / \mathrm{l}$. The results show that EBC is slightly 
buffered by a small amount of $\mathrm{HCO}_{3}{ }^{-}$, which is almost not altered during exercise; no acids seem to be added to the EBC under this condition. The $\mathrm{pH}$ of $\mathrm{EBC}$ is found to be near the $\mathrm{pK}$ of the $\mathrm{CO}_{2}$-bicarbonate system. After exercise, a small alkaline shift of $0.1 \mathrm{pH}$ is found, indicating, that no acids are added during exercise.

\section{Discussion}

Release of $\mathrm{H}_{2} \mathrm{O}_{2}$ in exhaled breath as a maker of oxidative stress and/or inflammatory processes increased during exhausting external load. We observed exercise induced alterations of blood $\mathrm{pH}$ and bicarbonate. $\mathrm{pH}$ and bicarbonate of the equilibrated EBC remained almost constant.

\section{$\mathrm{H}_{2} \mathrm{O}_{2}$ Concentrations in EBC}

$\mathrm{H}_{2} \mathrm{O}_{2}$ in $\mathrm{EBC}$ is unstable and has to be analyzed directly after collection or should be frozen for later analysis [6]. In our investigation samples were stored in a cooling unit on ice cubes at $-20^{\circ} \mathrm{C}$. Analysis was performed within $90 \mathrm{~min}$ after collection. So, no major loss of $\mathrm{H}_{2} \mathrm{O}_{2}$ should be considered.

A number of studies reported from highly variable concentrations of $\mathrm{H}_{2} \mathrm{O}_{2}$ for healthy adults ranging from $\leq 50 \mathrm{nmol} / 1 \mathrm{EBC}$ [7] through 250-300 nmol/1 $\mathrm{EBC}[8,9]$, up to $480 \mathrm{nmol} / 1$ [10]. One reason could be that the collection time is different from subject to subject. The higher the ventilation the greater is the dilution of the exhaled breath. Thus, it seems necessary to calculate the release of $\mathrm{H}_{2} \mathrm{O}_{2}$ in both exhaled breath and EBC. A other reason could be that there is an intra-individual release of markers like $\mathrm{H}_{2} \mathrm{O}_{2}$ in the EBC [11].

\section{$\mathrm{H}_{2} \mathrm{O}_{2}$ AS AN INFLAMMATORY MARKER OF LUNG DiSEASES}

In the respiratory tract, $\mathrm{H}_{2} \mathrm{O}_{2}$ is released from neutrophils and eosinophils and from macrophages and epithelial cells [12] in inflammatory processes. Compared with healthy subjects, increased level of $\mathrm{H}_{2} \mathrm{O}_{2}$ concentrations can be find in EBC from smokers [13], patients with bronchial asthma [14-17], COPD [14, 16, 18-21], bronchiectasis [8, 22] cystic fibrosis [23, 24], and ARDS $[24,25]$. In induced sputum, $\mathrm{H}_{2} \mathrm{O}_{2}$-concetrations at moderate asthma correlated to the amount of eosinophiles and airway responsiveness [26].

$\mathrm{H}_{2} \mathrm{O}_{2}$ as an inflammatory marker is of special interest for time course of disease and the therapy control of asthma. Under inhaled steroid therapy the altered $\mathrm{H}_{2} \mathrm{O}_{2}$ concentration in EBS reversal [31], exacerbations of COPD cause increased levels of $\mathrm{H}_{2} \mathrm{O}_{2}$ compared to stable phases [18]. First investigations show, that anti-oxidative therapy with $\mathrm{N}$-acetylcystein result in a decrease of $\left[\mathrm{H}_{2} \mathrm{O}_{2}\right]$ in EBC [20].

In our investigation at resting conditions a mean value for the $\mathrm{H}_{2} \mathrm{O}_{2}$ concentration of $190 \mathrm{nmol} / 1$ was measured in EBC. Individual values were ranging from 80 to $1330 \mathrm{nmol} / \mathrm{l}$. It is unknown whether the highest values derive from a subject with a symptom free fresh infection or from a contamination with saliva. A pro- cessing fault seems unlikely since the subject had the highest values also during exercise.

\section{OXIDATIVE STRESS}

Physical exercise is characterised by an increase in reactive oxygen species (ROS) production [27]. The main sources of ROS during exercise are the mitochondrial respiratory chain, xanthine oxidase-catalyzed reaction, and neutrophils' activation. ROS are known to cause oxidative modifications of lipids, proteins and nucleic acids leading to cell and tissue damage [28]. $\mathrm{H}_{2} \mathrm{O}_{2}$ considered a ROS because of its capacity to cause ROS formation. Earlier studies have shown increased levels of oxidative stress associated with physical work [29], because $\mathrm{H}_{2} \mathrm{O}_{2}$ correlates well with the oxygen consumption at resting conditions, as well as under moderate and exhausting exercise [30]. The higher the oxygen consumption the greater is the $\mathrm{H}_{2} \mathrm{O}_{2}$-release in EBC, because $\mathrm{H}_{2} \mathrm{O}_{2}$ is produced after converting superoxide anions $\mathrm{O}_{2}{ }^{-}$to $\mathrm{H}_{2} \mathrm{O}_{2}$.

\section{Normal Values of Healthy Subjects}

In young and healthy non-smokers, Nowak et al. [9] reported $\mathrm{H}_{2} \mathrm{O}_{2}$ concentrations from 0.0 to $0.9 \mu \mathrm{mol} / \mathrm{l}$. Compared with young non smokers, the values were significantly increased in older healthy subjects and smokers [9]. The authors found a circadian rhythm in $\mathrm{H}_{2} \mathrm{O}_{2}$ concentration with the highest values at 12:00 and 24:00 o'clock. We found $\mathrm{H}_{2} \mathrm{O}_{2}$ concentrations of $190 \pm 169 \mathrm{nmol} / \mathrm{l}$, which are in accordance with the literature $(250-300 \mathrm{nmol} / \mathrm{l})[8,9]$. At rest, $\mathrm{H}_{2} \mathrm{O}_{2}$ release was $31 \pm 18.3 \mathrm{pmol} / \mathrm{min}$ and increased to $84.4 \pm 39.9$ $\mathrm{pmol} / \mathrm{min}$ at exhausting exercise. The results show a tendency of increased $\mathrm{H}_{2} \mathrm{O}_{2}$ concentration (2.5 times) during exercise, but a significant increase in $\mathrm{H}_{2} \mathrm{O}_{2}$ release during exercise $(\mathrm{P}<0.05)$, as a marker of oxidative stress in young and healthy subjects.

\section{pH of Exhaled Breath Condensate}

Acidification of the airways results in airway smooth muscle constriction [31], impaired ciliary motility [32], increases airway mucus viscosity [33], and damage of the airway epithelium [34]. These mechanisms are known to be involved in the development of airway inflammation. In patients with exacerbated asthma, COPD and bronchiectasis, the $\mathrm{pH}$ of $\mathrm{EBC}$ was essentially lower compared to normal conditions, and returned towards normal values after anti-inflammatory therapy and/or remission of exacerbations [35].

In healthy control subjects, Vaughan et al. [36] found a $\mathrm{pH}$ of $7.7 \pm 0.49$ in argon deaerated EBC samples with intraweek and intraday coefficients of variation of $4.5 \%$ and $3.5 \%$. The authors conclude that $\mathrm{pH}$ is mainly controlled by the lower airway source fluid. Kostikas et al. [35] reported a mean value of 7.56 for EBC pH of healthy subjects and lower values for patients with COPD (7.16) and bronchiectasis (7.11) moderate asthma (7.25). In steroid sensitive patients $\mathrm{pH}$ values normalized during therapy. In our investigation, we equilibrated the $\mathrm{EBC}$ solutions with $5 \% \mathrm{CO}_{2}$, conditions close to body fluids or epithelial 
lining fluid. In $\mathrm{CO}_{2}$ controlled $\mathrm{EBC}$, mean $\mathrm{pH}$ at rest was 6.08 , or 1.4 units lower compared with deaerated samples. After exhausting exercise, the mean $\mathrm{pH}$ was found at 6.18, which was not significantly different from resting values. In uncontrolled $\mathrm{CO}_{2}$ conditions, $\mathrm{pH}$ of EBC, measured within 15 min after collection was found at 6.99 under resting conditions and at 6.90 after exercise.

\section{EBC PH IN EXERCISE}

In an earlier study Riediker et al. [37] had shown an increase of EBC pH after $60 \mathrm{~min}$ post exercise. The exercise change on the treadmill was moderate and corresponded to fast walking. The $\mathrm{pH}$ increased by 0.07 , which was about one half to one fourth of the positive effect observed for inhaled corticosteroid therapy in asthmatics.

The $\mathrm{pH}$ of EBC is largely influenced by acids and bases which are released to maintain airway $\mathrm{pH}$ homeostasis of the airway extra cellular fluid. This fluid seems to be the source of the EBC the $\mathrm{pH}$ of which is in particular influenced by the $\mathrm{CO}_{2}$ of the lung compartment and by other acids and bases swept away by the airflow [38]. In healthy subjects we found an EBC $\mathrm{pH}$ of about 6.1 (near the $\mathrm{pK}$ of the $\mathrm{CO}_{2}$-bicarbonate buffer system, which is equilibrated with a gas mixture containing $5 \% \mathrm{CO}_{2}$, thus simulating the lung compartment in relation to $\mathrm{CO}_{2}$. However the bicarbonate concentration of EBC was found to be $1.1 \mathrm{mmol} / 1$. The $\mathrm{pH}$ of EBC is largely influenced by acids and bases which are released to maintain airway $\mathrm{pH}$ homeostasis of the airway extracellular fluid. This fluid seems to be the source of the EBC the $\mathrm{pH}$ of which is in particular influenced by the $\mathrm{CO}_{2}$ of the lung compartment and by other acids and bases swept away by the airflow [38].

Kullman et al. [5] could show that reproducibility of $\mathrm{pH}$ measurements in $5.3 \% \mathrm{CO}_{2}$ equilibrated EBC was 6 times higher compared to de aerated samples. $\mathrm{pH}$ in deaerated samples may be stable after 10 min of argon equilibration [6]; however these samples are not completely free from $\mathrm{CO}_{2}$ and its influence on $\mathrm{pH}$. From the physiological point of view, $\mathrm{pH}$ and acid base measurements should be performed under conditions as close to the normal conditions as possible, e.g., equilibrated with $5.3 \% \mathrm{CO}_{2}$. In future, measurements of $\mathrm{H}_{2} \mathrm{O}_{2}$ and acid-base parameters in EBC may become an effective tool for estimation of oxidative stress in sports and occupational medicine.

Conflicts of interest: No conflicts of interest were reported in relation to this article

\section{REFERENCES}

[1] Quanjer P, Tammeling GJ, Cotes JE, Pederson OF, Peslin $\mathrm{R}$, Yernault JC. Lung volumes and forced ventilatory flows. Report of the working party standardization of lung functions tests. European Community for Steel and Coal. Eur Respir J 1993; 6 Suppl 16.

[2] Kohlrausch F. Praktische Physik . 23 ${ }^{\text {th }}$ ed. Stuttgart, Teubner Verlagsgesellschaft, 1986.

[3] Marek E, Mückenhoff K, Streckert HJ, Becher G, Marek W. Bestimmung von L-Laktat und $\mathrm{H}_{2} \mathrm{O}_{2}$ im Atemkonden- sat in Ruhe und unter leichter bis mittelgradiger Belastung. Pneumologie 2008; 62: 1-7.

[4] Marek E, Mückenhoff K, Streckert HJ, Becher G, Marek W. Bestimmungen von L-Laktat im Atemkondensat in Ruhe so wie bei fahrradergometrischen Belastungsuntersuchungen. Atemw.-Lungenkrkh 2008; 34: 252-260.

[5] Kullmann T, Barta I, Lazar Z, Szili B, Barat E, Valyon M, Kollai M, Horvarth I. Exhaled breath condensate $\mathrm{pH}$ standardised for $\mathrm{CO}_{2}$ partial pressure. Eur Respir J 2007: 29: 496-501.

[6] Horvarth I, Hunt J, Barnes PJ. Exhaled breath condensate: methodological recommendations and unresolved questions. Eur Respir J 2005; 26: 523-548.

[7] Gerritsen WB, Zanen P, Bauwens AA, van den Bosch JM, Haas FJ. Validation of a new method to measure hydrogen peroxide in exhaled breath condensate. Respir Med 2005; 99: 1132-1137.

[8] Loukides S, Bouros D, Papatheodorou G, Lachanis S, Panagou P, Siafakas NM. Exhaled $\mathrm{H}_{2} \mathrm{O}_{2}$ in steady-state bronchiectasis: relationship with cellular composition in induced sputum, spirometry, and extent and severity of disease. Chest 2002; 121(1): 81-87.

[9] Nowak D, Kalucka S, Bialasiewicz P, Krol M. Exhalation of $\mathrm{H}_{2} \mathrm{O}_{2}$ and thiobarbituric acid reactive substances (TBARs) in healthy subjects. Free Radic Biol Med 2001; 30:178-186

[10] Svensson S, Ölin AC, Lärstad M, Ljungkvist G, Torén K. Determination of hydrogen peroxide in exhaled breath condensate by flow injection analysis with fluorescence detection. J Chromatogr B Analyt Technol Biomed Life Sci 2004; 809(2): 199-203.

[11] Knobloch H, Becher G, Decker M, Reinhold P. Evaluation of $\mathrm{H}_{2} \mathrm{O}_{2}$ and $\mathrm{pH}$ in exhaled breath condensate samples: methodical and physiological aspects. Biomarkers 2008; 13(3): 319-341.

[12] Conner GE, Salathe M, Forteza R. Lactoperoxidase and hydrogen peroxide metabolism in the airways. Am J Respir Crit Care Med 2002; 166(12): S57-S61.

[13] Nowak D, Antczak A, Krol M, Pietras T, Shariati B, Bialasiewicz P, Jeczkowski K, Kula P. Increased content of hydrogen peroxide in the expired breath of cigarette smokers. Eur Respir J 1996; 9(4): 652-657.

[14] Shephard RJ. Physiology and Biochemistry of exercise. New York: Praeger Publishers, 1982.

[15] van Beurden WJ, Dekhuijzen PN, Harff GA, Smeenk FW. Variability of exhaled hydrogren peroxide in stable COPD patients and matched healthy controls. Respiration 2002; 69(3): 211-216.

[16] Dohlmann AW, Black HR, Royall JA. Expired breath hydrogen peroxide is a marker of acute airway inflammation. Am Rev Respir Dis 1993; 148: 955-960.

[17] Antczak A, Kurmanowska Z, Kasielski M, Nowak D. In creased hydrogen peroxide and thiobarbituric acid-reactive products in expired breath condensate of asthmatic patients. Eur Respir J 1997;10: 1235-1241.

[18] Dekhuijzen PN, Aben KK, Dekker I, Aarts LP, Wielders PL, van Herwaarden CL, Bast A. Increased exhalation of hydrogen peroxide in patients with stable and unstable chronic obstructive pulmonary disease. Am J Respir Crit Care Med 1996; 154(3): 813-816.

[19] Nowak D, Kasielski M, Pietras T, Bialasiewicz P, Antczak A. Cigarette smoking does not increase hydrogen peroxide levels in expired breath condensate of patients with stable COPD. Monaldi Arch Chest Dis 1998; 53(3): 268273.

[20] Kasielski M, Nowak D. Long term administration of Nacetylcysteine decreases hydrogen peroxide exhalation in subjects with chronic obstructive pulmonary disease. Respir Med 2001; 95(6): 448-456.

[21] De Benedetto F, Aceto A, Dragani B, Spacone A, Formisano S, Cocco R, Sanguinetti CM. Validation of a 
new technique to assess exhaled hydrogen peroxide: results from normals and COPD patients. Monaldi Arch Chest Dis 2000; 55(3): 185-188.

[22] Loukides S, Horvarth I, Wodehouse T, Cole PJ, Barnes PJ. Elevated levels of exipired breath hydrogen peroxide in bronchiectasis. Am J Respir Crit Care Med 1998; 158(3): 991-1004.

[23] Worlitz D, Herberth G, Ulrich M, Döring G. Catalase, myeoperoxide and hydrogen peroxide in cystic fibrosis. Eur Respir J 1998; 11(2): 377-383.

[24] Baldwin SR, Simon RH, Grum CM, Ketai LH, Boxer LA, Devall LJ. Oxidant activity in expired breath of patients with adult respiratory stress syndrome. Lancet 1986; 18471: 11-14.

[25] Heard SO, Longtine K, Toth I, Puyana JC, Potenza B, Smyrnios N. The influence of liposome-encapsulated Prostaglandin E1 on hydrogen peroxide on hydrogen peroxide concentrations in the exhaled breath of patients with the acute respiratory stress syndrome. Anesth Analg 1999; 89(2): 353-357.

[26] Horvarth I, Donnelly LE, Kiss A, Kharitonow SA, Lim S, Fan Chung K, Barnes PJ. Combined use of exhaled hydrogen peroxide and nitric oxide in monitoring asthma. Am J Respir Crit Care Med 1998; 158(4): 1042-1046.

[27] Lachance PA, Nakat Z, Jeong WS. Antioxidants: an integrative approach. Nutrition 2001; 17: 835-838.

[28] Sen CK. Antioxidant and redox regulation of cellular signalling. Med Sci Sports Exerc 2001; 33(3): 368-370.

[29] Schmidt MC, Askev EW, Roberts DE, Prior RL, Ensign WY Jr, Hesslink RE Jr. Oxidative stress in humans training in a cold, moderate altitude environment and their response to a phytochemical atioxidant supplement. Wilderness Environ Med 2002; 13: 94-105.

[30] Heinicke I, Boehler A, Rechsteiner T, Bogdanova A, Jelkmann W, Hofer M, Rawlings P, Araneda OF, Behn C, Gassmann M. Moderate altitude but not additional endurance training increases markers of oxidative stress in exhaled breath condensate. Eur J Appl Physiol Epub. 2009.

[31] Ricciardolo FLM, Rado V, Fabbri LM, Sterk PJ, Di Maria GU, Geppeti P. Bronchoconstriction induced by citric acid inhalation in guinea pigs: role of tachykinins, bradykinin, and nitric oxide. Am J Respir Crit Care Med 1999; 159: 557-562.
[32] Luk CK, Dulfano MJ. Effect of $\mathrm{pH}$, viscosity and ionic strength changes in ciliary beating frequency of human bronchial explants. Clin Sci Lond 1983; 64: 449-451.

[33] Holma B, Hegg PO. pH and protein-dependent buffer capacity and viscosity of respiratory mucus: their interrelationship and influence on health. Sci Total Environ 1989; 84: 71-82.

[34] Holma B, Lindgren M, Andersen JM. pH effects on ciliomotility and morphology of respiratory mucosa. Arch Environ Health 1977; 32: 216-226.

[35] Kostikas K, Papatheodorou G, Ganas K, Psathakis K, Panagou P, Loukides S. pH in expired breath condensate of patients with inflammatory airway diseases. Am J Respir Crit Care Med 2002; 165: 1364-1370.

[36] Vaughan J, Ngamtrakulparit L, Pajewski TN. Exhaled breath condensate $\mathrm{pH}$ is a robust and reproducibly assay of airway acidity. Eur Respir J 2003; 22: 889-894.

[37] Riedecker M, Danuser B. Exhaled breath condensate $\mathrm{pH}$ is increased after moderate exercise. J Aerosol Med 2007; 20[1]: 13-18.

[38] Effros RM, Biller J, Foss B, Hoagland K, Dunning MS, Castillo D, Bosbous M, Sun F, Shaker R. A simple method for estimating respiratory solute dilution in $\mathrm{ex}$ haled breath condensates. Am J Respir Crit Care Med 2003; 168: 1500-1505.

Address for correspondence:

Eike Marek, BA arts,

Institute of Sportmedicine and Sportnutritition

Ruhr-University Bochum

Universitätsstr. 150

44801 Bochum

Germany

Phone: +492345172474

E-mail: Eike.Marek@rub.de 